\title{
The Kangaroo and the Dragon: Party Ideology and its Impacts on Australia's Methods of International Governance with China as a Case Study
}

\author{
Stjepan Bosnjak \\ Victoria University
}

\begin{abstract}
Australia's two main political groupings - the ALP and Coalition - represent two different methods of governance, based on their political ideologies. These differences extend to the external sphere. It is the overarching aim of states to gain power to pursue what they deem is in their national interests, though the definition and method of governance changes according to the party in power. Broadly, the Coalition prefers to focus on bilateral relationships in achieving its national interest, whereas the ALP focuses on achieving its national interest through multilateral settings. When in government, both sides puts the powers and resources of the state towards achieving their preferred method of governance, and neglecting the other. This paper will look at a history of post WWII Australian Prime Minister's methods of governance and then finish by engaging in a discussion of Australia's current issues with governance concerning its economic relationship with China.
\end{abstract}

\section{Key Words}

Governance, Foreign policy, Australian Labour Party, China

\begin{abstract}
ARTICLE
Copyright (C) 2015 Victoria University. This document has been published as part of the Journal Law and Governance in both online and print formats. Educational and non-profit institutions are granted a non-exclusive licence to utilise this document in whole or in part for personal or classroom use without fee, provided that correct attribution and citation are made and this copyright statement is reproduced. Any other usage is prohibited without the express permission of the publisher.
\end{abstract}

States use their power to achieve their own interests. Therefore, states that can direct more national resources are more powerful and have foreign policies that have more impact than weaker states. However, it is acknowledged in neoclassical realist approaches that foreign policy choices are made by a select few political leaders and elites. As they have the authority to utilise the national resources. It is their perceptions that matter and determine responses. Their view of a nation's power maybe different to the realities, and they are restrained from using a nation's full power by both internal and external factors ${ }^{1}$. To understand the way states respond to their external environment, the variables caused by internal pressures must be analysed. These variables include different political systems and structures, cultures and national identities and may restrict easy access to a state's total material power resources. ${ }^{2}$ Because of these domestic pressures on the perception and use of power, neoclassical realism also examines different state structures and understanding the links between power and policy. Neoclassical realism argues that it is the aim of states to gain power to pursue what they deem is in their national interests. It breaks down the state's efforts in that respect into two spheres, the internal and the external.

The external sphere is similar to other theories of realism, states competing against each other in an anarchical international order. The internal sphere is further broken into three domestic actants that effectively define the internal composition of the state itself: the elites, the political class and the public. It argues that it is the perceptions of power and the interests that the three actants have that

\footnotetext{
${ }^{1}$ Gideon Rose, "Neoclassical Realism and Theories of Foreign Policy", 1998, World Politics, Vol. 51, No 1, Oct., http://www.jstor.org/stable/25054068, p147

${ }^{2}$ Ibid p161
} 
matter in the method of governance of the state's international relations. Perceptions are shaped by experiences, culture history and ideology. Perceptions influence decisions, reactions and methods of governance at all levels and in Australia, our two main political groupings - the ALP and Coalition represent two different methods of governance, based on their perceptions. The Coalition prefers to focus on bilateral relationships, whereas the ALP focuses on achieving its national interest through multilateral institutions. Both sides aim to accomplish the same goal - the national interest, though, despite sharing some common ground, each has their own unique interpretations of what constitutes the national interest. Despite foreign policy in Australia being formed by a small number of people, the top two with ultimate responsibility, the Prime Minister and foreign minister, are heavily influenced by their party position and preferred method of governance. The rise of China has led to challenges to Australia's national interest, and both the ALP and Coalition argue that their method of governance is best suited to meet these challenges.

A political "party is a body of men united for promoting by their joint endeavours the national interest upon some particular principle in which they are all agreed" 3 The overarching foreign policy aim for both the ALP and Coalition is serving Australia's national interest. "National interest is a term used to denote the objectives pursued by a state" ${ }^{4}$ The term 'interest' is usually related to the realist view of international politics. Hans Morgenthau, one of the intellectual founding fathers of realism stated "The main signpost that helps political realism to find its way through the landscape of international politics is the concept of interest defined in terms of power" and "The statesman must think in terms of the national interest, conceived as power among other powers." 'National interest' is commonly used in association with foreign policy, the equivalent terms regarding domestic policy are 'public interest' or 'common good'. The ALP's and Coalition's definition of the national interest have four common goals: maintaining the territorial integrity of Australia, including the safety and security of its society and economy; ensuring regional stability and preserving the existing regional balance of power; the sea lanes that make up the arteries of international trade remain open; and responding to new security threats. ${ }^{7}$ Included in the last goal are terrorism, international crime, unregulated population movement, and quarantine.

To understand Australia's national interest objectives, we must comprehend Australia's sense of isolation and subliminal fear of invasion. Australians comprise less than one-third of one per cent of the world's population. This tiny fraction of humanity lives on an island continent, comprising just over 5 per cent of the earth's land surface. This continent contains unique flora and fauna, not found anywhere else in the world and is abundant in primary resources. It does not have a land border with any other country. Its east and west coasts face nothing but ocean, to the south are the frozen expanses of the Antarctic. To the north are cultures and civilisations with that seem alien and exotic and to most Australians. Australia's geostrategic environment is the South Pacific and South East Asia. "Its major ally is in North America, 12,000km away. Its major trading partners lie in North East Asia, $8000 \mathrm{~km}$ away. The historical and cultural roots of the majority of its population lie in Europe, on the other side of the world." ${ }^{8}$ Throughout its history, Australia has looked towards bigger powers to protect it from the outside world.

Due to the enormous and complex nature of foreign policy and the multiple, competing demands on their time, the most authoritative figures - the Prime Minister, the Minister of Foreign Affairs and senior advisors and secretaries, while wielding great influence, cannot attend to all policy matters, and their

\footnotetext{
${ }^{3}$ Edmund Burke, 1886, Thoughts on the cause of the present discontents,

http://www.unilibrary.com/ebooks/Burke,\%20Edmund\%20-\%20Thoughts\%20on\%20Present\%20Discontents.pdf

${ }^{4}$ Derek McDougall, 1997, Studies in International Relations: The Asia-Pacific, The Nuclear Age, Australia, Second Edition, Hodder Education, Rydalmere p23

${ }^{5}$ Hans Morgenthau, 1967, Politics Among Nations: The Struggle for Power and Peace, Alfred A. Knopf, New York, p5

${ }^{6}$ Ibid p 165

${ }^{7}$ Nick Bisley, 2012, "Never having to choose: China's rise and Australian Security" in Australia and China at 40, University of New South Wales, Sydney, p67-68

${ }^{8}$ Allan Gyngell \& Michael Wesley, 2003, Making Australian Foreign Policy, Cambridge University Press, Port Melbourne, p10
} 
fields of expertise does not extend to all fields, so can only exert their influence on certain matters. The Prime Minister sets the tone and direction of foreign policy due to the virtue of their position, which, despite, or because of the Constitution not mentioning the Prime Minister or their powers, in the Australian 'Washminster' system of government, enjoys unfettered authority in most areas of policy. When the Prime Minister makes a statement it is automatically viewed as policy and remains so unless retracted or it is overtaken by unforseen events. Despite only being elected by one electorate, The Prime Minister is perceived to speak for the entire nation and because of this acts as the key link between the internal and external spheres of governance. Because Australia's Head of State resides in the United Kingdom, and when abroad, mainly represents the interests of that country, the Prime Minister of Australia has the added responsibility of a de facto Head of State, as well as Head of Government. As mentioned previously, the Prime Minister cannot insert themselves into aspect of every foreign policy, so the policies they do pick and choose are inevitably given a high profile and priority, with relevant funding attached. The main difference between the Prime Minister and the Minister for Foreign Affairs is "...the Prime Minister can chose when to intervene, the Minister (for Foreign Affairs) cannot." "Most of the day-to- day decision making at operational level and most of the responsibility for the general direction of policy is left to the Foreign Affairs Minister. They share DFAT with the Minister for Trade, though takes overall administrative responsibility for the department.

The Coalition takes a pragmatic view to foreign policy, having a history of compartmentalising politics and trade. Australia was trading with the PRC under Menzies, at a time before it granted diplomatic recognition, and even while Australian troops fought and died in Vietnam - which was justified as an attempt to stop Chinese aggression - Australia was selling wheat, wool and steel to the PRC ${ }^{10}$. Promoting the bilateral method of governance allows for closer relationships to develop between nations, as elites establish rapport and friendship with each other. This reduces the possibility of instability and conflict developing by addressing problems before they can be exacerbated. Coalition governments also have a history of publicly appealing to 'Australian values', i.e., western values we have adopted from the English and share with the Americans. The flipside of this is that this often exacerbates xenophobic and racist undertones in Australian society against other cultures. Australia has free trade agreements (FTAs) with six different nations. They are in order: New Zealand (1965 \& 1983), United States (2004), Chile (2008), South Korea (2014), Japan (2014) and China (2014). Negotiations or ratifications for all six FTAs have occurred under Coalition governments, as the Coalition places high priority on bilateral relations so dedicates more of their ministers time on pursuing this method of governance. Historically, the Coalition has been more willing to send Australian troops to serve on overseas operations.

Trade and economics take a central role in the Liberal version of the national interest. As the major partner in the Coalition, it is the Liberal's ideology that is dominant. The Liberal Party's manifesto The Federal Platform outlines the party's ideologies, including its foreign policy aims:

further develop the capacity of an internationally competitive Australian economy to benefit from the globalisation of trade and investment flows;

maintain a strong national defence capability, with an appropriate mix of bilateral, regional and multilateral security alliances;

strengthen our international relationships and alliances, especially with the United States;

maximise the economic and strategic opportunities offered by closer engagement with the countries of the Asia-Pacific region; ${ }^{11}$

Therefore, as the major party in the Coalition the Liberal's governance when in power strives to achieve the aims stated in the manifesto.

The ALP's method of foreign policy governance has a history of using multilateral engagement as its tool of governance to meet its national interest aims. Whenever the ALP is in power Australia has

\footnotetext{
${ }^{9}$ Ibid p97

${ }^{10}$ James Curran, 2012, "The world changes: Australia's China policy in the wake of empire" in Australia and China at 40,

University of New South Wales, Sydney, p28

${ }^{11}$ Brian Loughnane (auth), 2002, The Federal Platform of the Liberal Party of Australia, Liberal Party of Australia,

http://lpaweb-static.s3.amazonaws.com/FederalPlatform.pdf
} 
stressed the importance of going through multilateral organisations, such as the United Nations, G20, or APEC when engaging in dialogue with a great power, especially on regional issues. This is because it believes all nations are equal in a multilateral environment. This equality ensures the influence of middle powers such as Australia is magnified, and the influence of greater powers is diluted. Greater powers are forced to constrain their ambitions, acknowledge the interests of multiple stakeholders and are placed under pressure to conform with majority opinion. In addition to this, Australia is a highly trade-dependent economy without the military throw-weight of a great power, and the ALP believes that without strong international rules and institutions would make the world a 'dog eat dog' place and disastrous to not only the national interest but the nation's survival. An example of the ALP's dedication to multilateral institutions is the UN Security Council. Australia has been a member of the UN Security Council on five occasions - 1946-74, 1956-57, 1973-74, 1985-86 and 2013-14. On all but one occasion (1956-57) it was ALP that campaigned to win the seat while in power.

The ALP tends to define Australia's national interest to include more idealistic, humanitarian aims. The ALP's manifesto The National Platform outlines the party's ideologies, including its foreign policy aims:

19 Labor defends Australia's national security, promotes our national interest and protects human rights.

For more than a century, Labor has played a significant role in defending our national security, fighting against oppression and injustice and supporting international efforts for peace and development. While the challenges change, our resolve to protect Australia does not. As a nation, we can give no greater respect than to those who take up military service in the defence of Australia and of our values in the world. We honour and cherish our military veterans for their proud contribution to our nation and their willingness to sacrifice themselves for our common good.

20 Labor believes Australia's interests are best protected and advanced by promoting peace and cooperation, including through our historic alliance with the United States, international forums like the United Nations, engaging with Asia, through public diplomacy and overseas aid and development.

22 Labor is a party of human rights. Labor believes in a just and tolerant society that fully protects the rights and freedoms of all people in Australia. Labor supports the Universal Declaration of Human Rights and the international treaties to which we are a signatory. ${ }^{12}$

Therefore the ALP's governance when in power strives to achieve the aims stated in the manifesto.

Prior to World War II, Australia's preferred method of governance in foreign affairs by the main party's was toeing London's line. Menzies summed it up as "saying useful things at the right time to the government of the United Kingdom" "13 Australia was content to see itself as an outpost of the British Empire and its citizens as British citizens. Australia refused to ratify the 1931 Statute of Westminster which gave autonomy to the whiter parts of the British Empire, with Menzies telling parliament "I know that quite a number of responsible people are troubled about the proposal to adopt the Statute of Westminster for the reason that they feel it may give some support to the idea of separatism from Great Britain." 14 Menzies further portrayed Australia's Britishness following the outbreak of World War II. He broke the news of hostilities by announcing "My fellow Australians...in consequence of the persistence by Germany in her invasion of Poland, Great Britain has declared war upon her, and that, as a result, Australia is also at war" ${ }^{15}$ Australia did not appoint an ambassador until 1940, following twelve months of negotiations, when Menzies reluctantly sent one to Washington, and even then it was only because of World War II. ${ }^{16}$ This imperial view was set to be shaken up, as World War II progressed, helped along by the election victory of John Curtin over Menzies in 1941. It was only during Chifley's government in 1948 that Australian citizenship was established.

\footnotetext{
12 George Wright (auth), 2011, Australian Labor Party National Platform, Australian Labor Party, http://d3n8a8pro7vhmx.cloudfront net/australianlaborparty/pages/121/attachments/original/1365135867/Labor_National_Pla tform.pdf?1365135867

${ }^{13}$ Robert Menzies, quoted in Peter Hartcher, 2014, The Adolescent Country, The Lowy Institute, Penguin, Melbourne, p78

${ }^{14}$ Robert Menzies, quoted in Paul Keating, Embargoed against delivery, Asia in the New Order: Australia's Diminishing Sphere of Influence, The Keith Murdoch Oration State Library of Victoria

14 November 2012

${ }^{15}$ Robert Menzies, Wartime Broadcast, 3 September 1939, https://www.awm.gov.au/encyclopedia/prime_ministers/menzies/

${ }^{16}$ Hartcher, The Adolescent Country, p78
} 
Curtin's entire period as Prime Minister was taken up by World War II. It was during this period that Australia began to fall under America's sphere of influence, with Curtin saying that "Australia looks to America, free of any pangs as to our traditional links or kinship with the United Kingdom." ${ }^{17}$ Singapore fell to the Japanese in February 1942, destroying Britain's ability to project power in the Pacific. in late 1942, under Curtin and his Minister for External Affairs Dr. H.V Evatt, the Australian Parliament passed the Statute of Westminster Adoption Act 1942. With this Act, Australia became legally autonomous from the United Kingdom, and with this new found autonomy, the ability to create its own foreign policy. Britain's war strategy had most Australian troops fighting the Axis in the Middle East. Following the outbreak of war in the, Curtin requested Australia's troops be returned. Churchill refused. Curtin ignored him and had two divisions brought back to defend Australia. However, as the tide of the war turned in favour of the allies, Curtin reverted back to type, calling Australia "the bastion of British institutions, the British way of life and the system of democratic government in the Southern World"18 while visiting London.

Ben Chifley's Prime Ministership dealt with the aftermath of World War II. He was a strong proponent of national self determination. He expressed the view that the "labour movement had a great objective - the light on the hill - which we aim to reach by working for the betterment of mankind...Labor would 'bring something better to the people, better standards of living, greater happiness to the mass of the people" 19 This speech has resonated through the decades, as it encapsulates the ALP's guiding philosophy. In foreign affairs he strongly resisted Dutch efforts to retake the Dutch East Indies. He also refused to send forces to help the British fight the insurgency in their colony of Malaya. These foreign policy decisions are consistent with the values explained by Chifley's 'light on the hill' speech.

Dr H.V Evatt is the ideological forefather of the ALP's multilateral method of governance. He helped establish the United Nations, contributing to the drafting of the Universal Declaration of Human Rights, served as the third President of the UN General Assembly, and the first Chairman of the UN Atomic Energy Commission. Though Evatt never had the opportunity to become Prime Minister, he was very influential in the Curtin-Chiefly ALP governments during World War II, serving variously and sometimes concurrently as Deputy Prime Minister, Attorney General and Minister for External Affairs, and later served as Opposition Leader during the Menzies government.

Robert Menzies became Prime Minister for the second time the Cold War was settling into the international landscape. Australia's traditional fear of the 'yellow peril' of being swamped by Asians was now exacerbated by the 'red peril' of communist invasion, forming the 'orange peril', which though vague, was at various times taken to mean Communist China, North Korea, Indo-China, Malaysia and Indonesia. Menzies committed Australian forces to the Korean War (1950-1953), the Malayan Emergency (1950-1960), Konfrontasi (1963-1966) and Vietnam (1962-1973) with the overarching aim To prevent the domino theory and stop the orange peril reaching Australia, and cement the bilateral relationship with the United States. Following the 1950 communist victory in China, Australian foreign policy was in two camps, due to Australia's transition period between British and American spheres of influence: those wishing to follow the British lead and extend recognition on the basis of "The People's Republic was in effective control of China irrespective of whether one liked that government or not"; and those wishing to follow the American argument that the communists "...had to show that it had the support of the Chinese people and was an acceptable member of the international community" ${ }^{21}$ The American argument won.

The US was keen to normalise relations with Japan so it could focus its energies on fighting the Korean War, but Australia was apprehensive of what could happen if the US rearmed Japan in its fight against communism, given that World War II was still fresh. In 1952 Australia signed the ANZUS Treaty with

\footnotetext{
${ }^{17}$ John Curtin, The Task Ahead, The Herald, 27 December 1941

18 John Curtin, the postscript to the news bulletin, Times, 7 May 1944

${ }^{19}$ Ben Chifley, speech to the NSW Labor Party Annual Conference, $12^{\text {th }}$ June 1949, http://www.chifley.org.au/the-light-onthe-hill/

${ }^{20}$ Robert Menzies in Derek McDougall, Studies in International Relations, p403

${ }^{21}$ Ibid
} 
the United States and New Zealand as a security guarantee compromise over these fears. Despite this, in 1957 Australia became the first nation to open its trading doors to Japan following World War II ${ }^{22}$ and Japan steadily grew to be Australia's major trading partner. When announcing that Australia was sending troops to South Vietnam, Menzies said "The take-over of South Vietnam would be a direct military threat to Australia...it must be seen as a thrust by Communist China between the Indian and Pacific Oceans. ${ }^{" 23}$ Conscription was controversially introduced to meet the manpower requirements for these overseas wars.

Australia's first large scale trade with the PRC occurred in 1960, when it started trading wheat ${ }^{24}$, later expanding to other primary produce such as wool, despite not recognising the PRC as the legitimate government of China. Australian troops had fought the Chinese during the 1950-1953 Korean War and only a couple of years after the establishment of the wheat trade between the two, Australia got involved in the Vietnam War, where the PRC sent military advisors. There was some controversy about Australia still selling wheat to the PRC while in Vietnam with accusations of 'we are feeding the enemy'. In 1962-1964, exports to PRC was 6\% of Australia's total ${ }^{25}$. In 1963-1964, one third of Australian wheat went to the PRC, worth $\$ 128.2$ million. ${ }^{26}$ Menzies argued that it was possible to compartmentalise trade and politics. The other partner in the Coalition, the Country Party also needed to placate its core rural constituency. Country Party leader, and Deputy Prime Minister John McEwen justified the position by saying "I know of no incident in history where peace and goodwill have been fostered by a government setting out to deny the people of another country ordinary foodstuffs." ${ }^{, 27}$ Menzies set the foreign policy tone for his next three successors as Prime Minister (not including the caretaker period of McEwen), who were all Liberals, with the exception of starting to draw down from the Vietnam War, and even then only in the face of massive domestic resistance.

Harold Holt was in office for just under two years before disappearing while swimming off Cheviot Beach. He responded to the withdrawal of British Empire from Asia by going 'all the way with LBJ', increasing Australia's commitment to the Vietnam War to boost ties with the United States.

John Gorton became Prime Minister after Holt's disappearance. He was viewed as a larrikin, and maverick by many Coalition elites. He viewed himself as 'Australian to the boot heels' ${ }^{28}$, and as such, sought to guide an independent foreign policy, while juggling the interests of Britain and the United States in the Cold War. He further distanced Australia from Britain and began the withdrawal of troops from Vietnam in November 1970, as the war was becoming more and more unpopular. Gorton "declared he was not of, or in, the Establishment" 29 and "Any future (ideological) changes were unlikely" to be in a conservative direction" ${ }^{30}$ This sort of governance style did not endear Gorton to his colleagues and he was deposed in a leadership ballot, where with the votes tied 33-33, Gorton seeing he did not have the party's support, cast his own vote to depart the leadership.

In direct contrast to Gorton, William McMahon described himself as a 'Liberal Party man' as it was the "organ by which the national will and conscience will be put into effect" ${ }^{31}$ His major foreign policy legacy is denouncing the July 1971 Gough Whitlam led delegation to the People's Republic of China

\footnotetext{
${ }^{22}$ Annabelle Quince \& Kerry Phillips, Trading with the enemy: the Australia-Japan Agreement on Commerce, ABC, 25 February 2007, http://www.abc net.au/radionational/programs/rearvision/trading-with-the-enemy-the-australiajapan/3393730 accessed 6 March 2015

${ }_{23}^{23}$ Robert Menzies in Derek McDougall, Studies in International Relations, p404

${ }^{24}$ Peg White \& Peter Young, 1988, Australia's Relations with Asia, McGraw-Hill Book Company, Sydney p121

${ }^{25}$ ESK Fung and C Mackerras, 1985, From Fear to Friendship; Australia's Policies towards the Peoples Republic of China,

1966-1982, University of Queensland Press, Brisbane, p84

${ }^{26}$ Ibid, p83

${ }^{27}$ John McEwen in Derek McDougall, Studies in International Relations, p405

${ }^{28}$ John Gorton, Australia's Prime Ministers, National Archives of Australia, http://primeministers naa.gov.au/primeministers/gorton/in-office.aspx

${ }^{29}$ Ian Hancock, 2002 John Gorton: He Did It His Way, Hodder, Sydney p248

${ }^{30}$ Ibid

${ }^{31}$ William McMahon, New Prime Minister's Press Conference, 10 March 1971, http://pmtranscripts.dpmc.gov.au/transcripts/00002381.pdf
} 
as proof that Whitlam was "a pawn of a Communist power and a spokesman for the enemy being fought in Vietnam"32 Only weeks later, McMahon faced widespread public humiliation when US President Richard Nixon announced he would be visiting the PRC. Also in July 1971 the Coalition cabinet agreed on withdrawing Australian forces from Vietnam, anticipating a US scale down in the face of the new Sino-US détente. By the end of McMahon's term, the majority of Australia's troops had been withdrawn from Vietnam.

Despite the exception of its most notable foreign policy achievement in being the first developed economy to recognise the People's Republic of China, the Whitlam government revived Evatt's multilateral method of governance in the external sphere. Whitlam spent almost a year as foreign minister as well as Prime Minister. Prior to Whitlam's term, the only multilateral organisation Australia's leaders participated in was the Commonwealth Heads of Government Meeting (CHOGM). Whitlam expanded this and Australia joined the Council for Namibia, the Ad Hoc Committee on the Indian Ocean and the Committee of Twenty-four on decolonisation, with Whitlam speaking at many Third World conferences. He created an international aid agency separate from DFAT and raised the proportion of aide given through multilateral channels by $5 \%{ }^{33}$ Under Whitlam Australia initiated a dialogue partnership with the Association of South East Asian Nations (ASEAN), pledging financial assistance to its aid development program. Some multilateral trade treaties adopted by the Whitlam government include the Arrangement regarding International Trade in Textiles, International Sugar Agreement, Agreement establishing the International Bauxite Association and ratifying nine International Labour Organisation (ILO) conventions. In regards to the PRC trade increased fivefold following diplomatic recognition. ${ }^{34}$ Whitlam believed "that international law - and by that I include...the formal and informal institutions - provides the only alternative to tension, chaos and destruction" 35 Australia (and New Zealand) took France to the International Court over its nuclear testing in the Pacific, ratified Nuclear Non-proliferation Treaty and promoted the region as 'a zone of peace'. Whitlam also renewed focus on the UN, which, as mentioned, his predecessor Evatt had helped establish, and had been lower down the list of priorities by Menzies. Whitlam stated "it is through the United Nations that Australia best asserts its national independence and international identity" ${ }^{36} \mathrm{He}$ backed up these words with actions, Australia contributed funds to assist educational development in Africa.

Unlike Whitlam, Malcolm Fraser was "not out to change the world"37 though he did play an important role in establishing an independent Zimbabwe and was a vocal critic of South Africa's apartheid. He was very worried about the threats of 'Soviet Imperialism' to the Australian national interest and promoted a boycott of the 1980 Moscow Olympics. In 1976 Fraser visited the PRC to promote trade relations, turning Whitlam's recognition of Beijing into a bipartisan one. He also concluded a friendship treaty with Japan, giving Japanese businesses favourable treatment. Fraser merged Whitlam's aid agency into DFAT, because the Coalition believes that aid is a tool that can be used to achieve the national interest.

In 1989 Bob Hawke proposed the creation of the Asia-Pacific Economic Cooperation group (APEC) as an informal multilateral method of economic governance. Bob Hawke's major foreign policy challenge came about in 1990 when Iraq invaded Kuwait. Australia fully participated in the UN sanctions placed on Iraq following the invasion and sent a contingent of over 1800 ADF personnel to the Gulf War, and

\footnotetext{
${ }^{32}$ William McMahon, Australia's Prime Ministers, National Archives of Australia, http://primeministers naa.gov.au/primeministers/mcmahon/in-office.aspx

${ }^{33}$ T.B Millar, From Whitlam to Fraser, Foreign Affairs, July 1977, http://www foreignaffairs.com/articles/27902/tbmillar/from-whitlam-to-fraser

${ }^{34}$ Jim Cairns, in interview with Robin Hughes, May 25, 1998,

http://www.australianbiography.gov.au/subjects/cairns/interview7 html, accessed 14 Jan 2013

${ }^{35}$ Gough Whitlam, Australia and International Law - Address by the Prime Minister to the Seminar on Public International Law, Canberra, 26 July 1975, Whitlam Institute E-Collection at 2,

http://cem.uws.edu.au/R/F6TBHIGNYUKUV33HDQBGXS19MQKA6S2D429T1M6H6QA9KDNV6Y00203 ? func $=$ results-jump-full\&set entry $=000001 \&$ set number $=000003 \&$ base $=$ GEN01-EGW0 1

${ }^{36}$ Gough Whitlam, 1997, Abiding Interests, University of Queensland Press, St Lucia, QLD, p171

${ }^{37}$ T.B Millar, From Whitlam to Fraser
} 
to provide humanitarian aid to Kurds in northern Iraq. ${ }^{38}$ Under Hawke, various high ranking Chinese officials visited Australia. In the 1980s, China's two largest foreign investments, worth a combined $\$ 310$ million were both in the Australian resources sector ${ }^{39}$. In 1984-1985, Australian exports exceeded $\$ 1$ billion $^{40}$, with wheat still accounting for $51 \%$ of exports. ${ }^{41}$ However, relations between the two nations soured following the Tiananmen Square massacre in June 1989, with the Hawke government, guided by its idealistic and humanitarian ideologies imposing sanctions on the PRC.

After deposing Hawke in December 1991, Paul Keating began pushing for a paradigm shift in Australian identity, moving from a nation bound by our ties to the UK towards one that identified as being part of the Asia-Pacific. The key to this change was APEC. He believed that regionalism had been stifled due to the bipolarity of the Cold War, but following the collapse of the Soviet Union it was now a possible method of governance. ${ }^{42}$ All previous Prime Ministers only attended two international gatherings - the Commonwealth Heads of Government Meeting and the South Pacific Forum. Keating wanted to change APEC from an informal meeting to the key multilateral institution in the region, responsible for the governance of developing free trade and economic cooperation between nations. $\mathrm{He}$ believed that a strong regional trade group was essential to Australia's economic stability. Keating spent his first 12 months as Prime Minister intensely lobbying fellow world leaders on his APEC dream, as he explains:

To succeed I first had to secure the support of the Japanese Prime Minister, then Kiichi Miyazawa. Miyazawa I had known well from my Treasury years but, in those days the Japanese would not do anything other than that countenanced by the United States. Miyazawa told me that he would only come with me if I was able to get Soeharto - not simply the President of Indonesia, but a leading figure in the Non-Aligned Movement: a big call. I made a huge effort with Soeharto; discussion after discussion, but once I had him, I was able to approach Li Peng, the Chinese Premier, to encourage China to come in too. Li Peng was exceptionally suspicious of it, particularly as APEC, the economic body, already had Taiwan and Hong Kong in its membership. But eventually I did get the support of Premier Li Peng for a head of government level, Pacific-wide body, but only after his wife had upbraided me at a dinner for putting unreasonable pressure on him. After I had added South Korea and Canada to the stock of states in support of the idea, I was able to approach President Bill Clinton for his support for what was virtually a custom made group. ${ }^{43}$

The first APEC Leaders' Meeting held in Seattle in November 1992.

Gareth Evans, became foreign minister in 1989, and as such served in both the Hawke and Keating governments, also succeeded in a number of multilateral initiatives, the most important being the ASEAN Regional Forum, the defence and security dialogue operating within the aegis of ASEAN. His most important legacy is the key role he played in the Cambodian peace process. The main obstacle to peace in Cambodia had been each of the internal warring parties wanting a disproportionate say in a power sharing agreement during a transitional administration. Three of the four parties wanted a power sharing agreement, though with more power for themselves than the others, and the other party rejected power sharing outright. To get around this impasse Evans publically announced that he supported "building a transitional administration directly around the authority of the United Nations... to decide the country's destiny pending free and fair elections organised by the UN and held under international supervision." ${ }^{44}$ This suggestion was taken up all parties involved, and the result was in 1992-93 the biggest and most far reaching UN peacekeeping operation ever mounted, the UN Transitional Authority

\footnotetext{
${ }^{38}$ 1980s, 90s and Gulf War, Royal Australian Air Force, http://web.archive.org/web/20070704204923/http://www.defence.gov.au/Raaf/history/airforce_history/gulfwar htm accessed 27th February 2015

${ }^{39}$ Ross Garnaut, Ross, 1990, Australia and the Northeast Asian Ascendancy: Report to the Prime Minister and the Minister for Foreign Affairs and Trade, Second Edition, Australian Government Publishing Service, Canberra, pg. 98

${ }^{40}$ FA Mediansky \& AC Palfreeman, eds., In Pursuit of National Interests: Australian Foreign Policy in the 1990s, Pergamon Press, Sydney, 1988

${ }^{41}$ White \& Young, 1988, Australia's Relations with Asia, pg. 123

42 Paul Keating, Embargoed against delivery, Asia in the New Order: Australia's Diminishing Sphere of Influence, 14

November 2012, The Keith Murdoch Oration State Library of Victoria

${ }^{43} \mathrm{Ibid}$

${ }^{44}$ Gareth Evans, Outline of the Cambodian Peace Plan, Extract from Australian Senate Hansard, 24 November 1989,

http://www.gevans.org/speeches/old/1989/241189_fm_outlinecambodia.pdf
} 
in Cambodia (UNTAC). Australia, in recognition of the key role Evans played assumed leadership of UNTAC. Evans explained why he was interested in Cambodia:

...we have, as a nation which aspires to be a good international citizen, an uncomplicated humanitarian obligation to help resolve the tragedy that has engulfed Cambodia. The people of Cambodia have been caught up in an external war not of their making; in a period of unimaginable internal horror; and in an external invasion that has brought with it further years of fighting, hunger and suffering. All the countries of the world owe the Cambodian people peace: to rebuild their country, their own lives and some kind of decent future for their children. ${ }^{45}$

After resigning from Australian politics in 1999 Evans has continued his high profile career in public life, joining several influential international think tanks dedicated to protecting world peace and human rights. Evans contributed to the creation of the concept 'Responsibility to Protect' (R2P), which argues that a state loses its right to sovereignty if it fails to protect its citizens from atrocities. Evans explains "It was to create a new norm of international behaviour which states would feel ashamed to violate, compelled to observe, or at least embarrassed to ignore. It was to stimulate the creation of new institutional mechanisms, national and international, that would help translate that sense of moral and political obligation to protect into effective action." 46

The Howard Government made a conscious effort to shift Australian foreign policy governance away from the multilateralism of the Hawke-Keating government and focus on Australia's relations with individual nations. He took significant steps were taken to increase the Prime Minister's role in foreign policy making to a more US Presidential model. During his government's tenure, all appointments of Ambassadors and High Commissioners had to be vetted by Howard and Cabinet, replacing the previous system of the foreign minister making these decisions. He had a big influence on the appointment of all department heads. A Cabinet subcommittee, the National Security Committee was formed and its members were not confined to Cabinet members, with senior bureaucrats regularly participating. Because Howard chaired this committee he was able to increase his influence in foreign and strategic policy. Under Howard, the Australian Wheat Board was embroiled in scandal for bribing officials of Saddam Hussein's regime at a time of UN sanctions. By using the compartmentalising method of governance Howard was able to juggle the interests of many stakeholders. Howard's Minister for Foreign Affairs, Alexander Downer belittled the ALP's ideology by arguing that " Australian foreign policy must be based not on dreamy idealism, but on a clear-headed understanding of the power structures of the Asia-Pacific region. It is insufficient for Australian foreign policy makers simply to assert our priority lies in our own region. We need to understand the weight of various regional powers and how the interrelationships between those powers affect the underlying security of the region." ${ }^{47}$

Australia was one of the key members in the Global War on Terror (GWOT) deploying resources in Afghanistan and Iraq following 9/11. Howard and Bush had a close personal relationship, with Bush giving Howard the nickname 'man of steel' in May, $2003^{48}$ and a 'sheriff' ${ }^{49}$ (following years of jibes by Howard's detractors that he was America's deputy sheriff ${ }^{50}$ ) because of Howard's staunch support for Bush's foreign policy. The Howard government established a free trade agreement with the US and despite a rocky start, was able to deepen Australia's relationship with China. Howard's balancing of Australia's bilateral relationships with the US and with China is the defining feature of his foreign

${ }^{45}$ Gareth Evans, Australia, Indo-China and the Cambodian Peace Initiative, Address to the Sydney Institute, Sydney, 13 March 1990, http://www.gevans.org/speeches/old/1990/130390 fm ausindochinecambodia.pdf

${ }^{46}$ Gareth Evans, The Responsibility to Protect at 10: Progress, Challenges and Opportunities in the Asia Pacific, Address to APR2P/ GCR2P/ Stanley Foundation/ ICRtoP Conference, Phnom Penh, Cambodia, 26 February 2015, $\mathrm{http} / / /$ www.gevans.org/speeches/speech568 html

${ }^{47}$ Alexander Downer, Neither Isolated nor Isolationist: The Legacy of Australia's Close Engagement with Asia, 9 August 2000, speech to the Murdoch University Asia Research Centre, $\mathrm{http}: / /$ www foreignminister.gov.au/speeches/2000/000809 isolate html

${ }^{48}$ Bush lauds Howard as 'man of steel', Sydney Morning Herald, 4 May 2003, http://www.smh.com.au/articles/2003/05/04/1051987592763 html

${ }^{49}$ James Grubel, Bush's 'sheriff' comment causes a stir, The Age, 17 October 2003, http://www.theage.com.au/articles/2003/10/16/1065917555365.html

${ }^{50}$ Australia as regional police doctrine puts Howard in damage control, ABC, 27 September 1999, http://www.abc net.au/7.30/stories/s55116 htm 
policy legacy, and the most successful example of the Coalition's preferred method of governance. This is symbolised by the consecutive days in October 2003 when President George W Bush and President $\mathrm{Hu}$ Jintao addressed joint sittings of both houses of the Australian Parliament. By the end of the Howard government in 2007, China had become Australia's major trading partner.

Kevin Rudd was Prime Minister between 2007-10 and 2013. Inbetween these two bookends he was Foreign Minister During this six year period, he was the most influential person in Parliament regarding foreign affairs. His successor as Prime Minister, Julia Gillard told the ABC "Foreign policy is not my passion. It's not what I've spent my life doing... if I had a choice I'd probably more be in a school watching kids learn to read in Australia than here in Brussels at international meetings. ${ }^{, 51}$ During the depths of the Global Financial Crisis Rudd pushed for the G20 (of which Australia is a member) to be upgraded from a forum for financial ministers to a leadership summit and for it to be the primary international economic governance decision making body, instead of the G8 (of which Australia is not a member). Rudd believed in the G20 so much that in the months leading to the inaugural 2008 Washington leadership summit he spent a third of his time dedicated to the project ${ }^{52}$ The 2009 London G20 leadership summit has been hailed as the reason for stopping the collapse of the world economy and "in coming years, the London G20 summit will be seen as the most successful summit in history" Following its success Rudd unsuccessfully campaigned to have the G20 replace the UN as the primary international multilateral body ${ }^{54}$ Rudd focused his energies on other multilateral bodies, including the East Asia Summit, where he was "hugely influential" 55 in getting the US and Russia invited as members.

In his first term, Rudd characterised Australia's relationship with China as 'Zhengyou' (a true friend who can criticise). Rudd said that as a Zhengyou "The best way to prosecute our relationship with China is to be broad-based about it and not to pretend problems do not exist when they do... At the same time, [we should] not regard those problems as impeding the development of the rest of the relationship." 56 The Rudd government used its Zhengyou status (real or imaginary) to raise several issues with China, something his predecessor never did. He mentioned human rights abuses in the 2008 speech in Beijing; in 2009, Chinalco was blocked from buying Rio Tinto; the Defence White Paper named China as a threat and Rebiya Kadeer, the exiled Uyghur leader was allowed to attend the 2009 Melbourne International Film Festival. All of these instances are examples of the ALP's ideology including human rights in its method of governance.

Tony Abbott has a history of being an anglophile, stating on several occasions that Australia is firmly part of the Anglosphere, most notably in his autobiographical book Battlelines. ${ }^{57}$ When making a speech at the Heritage Foundation in Washington DC he said "few Australians would regard America as a foreign country" ${ }^{15}$ Tony Abbott hinted at the Coalition's China polic. In the same speech he mentions "Australia's foreign policy should be driven as much by our values as our interests." 59 Abbott has also stated he will tighten foreign investment laws, stating that no Chinese State-owned Enterprise would be allowed to invest in Australia under an Abbott government, appealing to Australian, western values. ${ }^{60}$

\footnotetext{
${ }^{51}$ Julia Gillard, The 7:30 Report, ABC, 5 October 2010, http://www.abc net.au/7.30/content/2010/s3030288 htm

${ }^{52}$ Hartcher, The Adolescent Country, p4

${ }^{53}$ Colin Bradford \& Johannes Linn, 'The April 2009 London G-20 Summit in Retrospect', The Brookings Institution, 5 April 2010, www.brookings.edu/research/opinions/2010/04/05-g20-summit-linn

${ }^{54}$ Kevin Rudd in Dennis Shanahan, Kevin Rudd spruiks merits of G20 to the UN, The Australian, 25 September 2009, http://www.theaustralian.com.au/news/world/kevin-rudd-spruiks-merits-of-g20-to-the-un/story-e6frg6so-1225779334335

${ }^{55}$ Hartcher, The Adolescent Country, p66

${ }^{56}$ Kevin Rudd in Phillip Coorey, How zhengyou Kevin is keeping everyone happy, 11April 2008, Sydney Morning Herald, http://www.smh.com.au/news/world/how-zhengyou-kevin-is-keeping-everyone-happy/2008/04/10/1207420587841.html

${ }^{57}$ Peter Hartcher, On the road to China, no Damascus conversion, 15 May 2012, Sydney Morning

Herald, http://www.smh.com.au/federal-politics/political-opinion/on-the-road-to-china-no-damascus-conversion-201205141ymw4 html\#ixzz2Ye9GXp00, accessed 20 July 2013

${ }^{58}$ Tony Abbott, 2012, Address to the Heritage Foundation, Washington D.C.,

http://www.tonyabbott.com.au/LatestNews/Speeches/tabid/88/ArticleType/ArticleView/ArticleID/8816/Default.aspx

${ }^{59} \mathrm{Ibid}$

${ }^{60}$ Tony Abbott, 2012, Address to AustCham Beijing, China,

http://www.tonyabbott.com.au/News/tabid/94/articleType/ArticleView/articleId/8818/Address-to-AustCham-BeijingChina.aspx
} 
However, on winning government, Abbott has been just as pragmatic as his Coalition predecessors when it comes to trade, maintaining the jingoistic rhetoric for his domestic audience. On taking power the Abbott Government continued the Coalition tradition of bilateral relations. The first priority of the new government was securing free trade agreements with South Korea, Japan and China. Within its first 12 months of government it has achieved these agreements, reflecting the enormous amount of resources, time, energy and political capital spent on accomplishing this priority. Australia was the first nation to back the US campaign against ISIS, deploying 400 airmen and 200 Special Forces personnel to the fight.

What is China's national interest? China's over riding aim is stability and legitimacy of Communist Party rule. Due to the lack of democracy, the Party does not rule by direct mandate of the people, but as a continuation of the ancient 'mandate of heaven', enjoyed by Chinese Emperors. The main key to keeping this mandate is through providing economic prosperity for the people. ${ }^{61}$ This has, in turn provided for the economic prosperity of almost every other nation in the world, including Australia. The other method of governance utilised in creating stability is the promotion of Chinese nationalism. China is in the unique position of having (in one form or another) existed for 5,000 years. For most of this time China has seen itself as the 'Middle Kingdom', the centre of gravity for the whole world and its people as innately superior. Other entities around its periphery acknowledged this by paying tribute. This belief was destroyed with the 'Century of Humiliation', in which China was subjugated to foreign powers, which, according to the Party, only ended with the communist victory in the civil war in 1949. The Party has set about recreating the previous mentality as the basis of China's social cohesion. Like other forms of nationalism, modern Chinese nationalism has led to xenophobic undertones, and belief that China needs to be more aggressive and influential in foreign affairs, as its power rises. ${ }^{62}$

Xi Jinping was elected Secretary General ${ }^{63}$ of the Chinese Communist Party in November 2012 for a ten year term. His political slogan 'The Chinese Dream' is, like all political slogans, more style than substance. However, it ties in with the Party's goals, envisioning “...a mighty nation reclaiming its rightful place in the world, not just economically but politically and culturally too." ${ }^{\circ 4} \mathrm{He}$ has taken a hawkish stance on most foreign policy issues, notably with Japan over the Diaoyu/Senkaku islets and with Vietnam, Malaysia, Brunei and the Philippines over the South China Sea. This hawkish stance is making other nations in the region uneasy, and pushes them closer to the US. Xi predicts that China will become the chief military power in the region by $2049^{65}$, a sign of how advanced the US military is compared to every other nation on earth. Like the Emperors of old, the Secretary General wields enormous power and influence on the direction of the country, however he does so within Party limits. Likewise, in Australia, the Prime Minister is the most powerful actor in the making of foreign policy, but is not the only actor.

How is this likely to affect Australia? For Australia, the $21^{\text {st }}$ Century is the 'Asian Century'. With the advent of the 'Asian Century' there has been a conscious paradigm shift focusing on Asia in every facet of Australian life. Government, business and education are all being pushed and pulled into influencing all three domestic actants to perceive their culture and identity as an 'Asia Pacific' nation, as opposed to Australia's traditional European background. Simultaneously, the 'tyranny of distance' is being replaced with the 'advantage of proximity' as the global centres of political and economic power shift closer to Australia's region. The People's Republic of China, more than any other Asian nation exemplifies the opportunities and pitfalls available in the Asian Century. While not part of China's periphery states, Australia is in a unique halfway point in regards to China. To put China's importance to Australia's economic health into perspective in 2005 “.... a ship load of iron ore was worth about the same as about 2,200 flat screen television sets. Today (2010) it is worth about 22,000 flat-screen TV

\footnotetext{
${ }^{61}$ Rowan Callick, Party Time: Who Runs China and How, Black Inc, Collingwood, p13

${ }^{62}$ Martin Jacques, When China Rules the World, $2^{\text {nd }}$ Edition, Penguin, London, p533

${ }^{63}$ For a description of the different titles and powers office bearers in Chinese politics have see Susan V. Lawrence and Michael F. Martin's Understanding China's Political System, Congressional Research Service Report for (US) Congress

${ }^{64}$ Beech, How China Sees the World, p21

${ }^{65}$ Ibid p20
} 
sets - partly due to TV prices falling but more due to the price of iron ore rising by a factor of six" Almost $30 \%$ of Australia's exports go to China. ${ }^{67}$ This economic dependence on China ensures that Australia will be affected by how China acts in its relations with other states in the region, seven of which are in Australia's top eight economic partners. ${ }^{68}$ From a Chinese perspective, Australia is viewed as a western, European nation in their region, and as such, Australia provides a window to the Chinese on how other western nations think, as our European culture has influenced our perceptions and reactions. Because of Australia's close relationship with the US, China also uses Australia as an intermediary to send diplomatic messages to the US.

"Australia is strikingly different from any country in Asia. But we are not uniquely different: no more different from China is Indonesia; no more different from Japan than is Malaysia; no more different from the Republic of Korea than is India." ${ }^{69}$ India, Singapore, South Korea and Taiwan are all part of China's geographical periphery. All have the United States as their major security partner and the PRC as their major economic one and they manage to juggle the two. Indeed, the latter two states owe their existence to American military support against the Chinese. Australia has even traded with China in a time of war, though it is hard to see that happening again. As China becomes the regional hegemon, it is well within its realpolitikal rights to exercise both its hard and soft power ${ }^{70}$ in influencing other states, including Australia. It will be up to the Australian Government on how to respond.

Australia's foreign policy methods of governance towards China following the 2013 election should be a continuation of Australia's foreign policy towards China in the 5 years preceding the 2013 election. To achieve its geopolitical national interest objectives, Australia needs to persuade other nations in the Asia-Pacific to encourage China to participate in regional forums, by convincing the Chinese it is worthwhile to do so, as China is easily powerful enough to ignore multilateral organisations. Because other nations in the region are facing a similar conundrum regarding China, Australia's middle power status will be enhanced if it presents a united front with these nations, when negotiating with China. The peer pressure advantages within the ALP's preferred multilateral method of governance is, by nature, unavailable to be replicated in the bilateral method preferred by the Coalition. However, the Coalition's bilateral method allows for more specific issues to be raised, and allows for closer relationships between nations, reducing the possibility of instability and conflict, by addressing problems before they are able to fester. Because of these advantages, Australia needs to continue its annual bilateral talks with China. The Howard government made great use of its bilateral relations with China, which have been strengthened under Gillard-Rudd. These talks should be used to raise issues that affect the relationship by both sides in more confidential and relaxed settings, with more time dedicated to the meetings than are afforded in a multilateral setting. As a leader's time is a finite resource, there needs to be a balance between the two, with the Prime Minister attending multilateral meetings and having other key players such as the foreign and trade ministers attend bilateral meetings with their counterparts. The ALP's national interest concerns involving human rights can be brought up in a bilateral setting, without embarrassing the other nation or compromising the relationship.

One thing both sides of politics need to agree on is that Australia is on the wrong end of the mining boom, though exports are still strong ${ }^{71}$, and will remain so for fifteen years ${ }^{72}$. It is predicted that China's urban population will increase by 326 million people $^{73}$, a number greater than the entire population of the United States. This urbanisation will still require Australian commodities to meet energy needs and

\footnotetext{
${ }^{66}$ Stevens, The Challenge of Prosperity,

${ }^{67}$ Beech, How China Sees the World, $\mathrm{p} 23$

${ }^{68}$ Australia's trade in goods and services by top ten partners, 2013, DFAT, $<\mathrm{http}: / /$ dfat.gov.au/publications/tgs/index html $>$ accessed 08 August 2014

${ }^{69}$ Ross Garnaut, Australia and the Northeast Asian Ascendancy p319

${ }^{70}$ See Zachary Keck's The Hard Side of Soft Power, The Diplomat, 24 July 2013, http://thediplomat.com/theeditor/2013/07/24/the-hard-side-of-soft-power/

${ }^{71}$ Kevin Rudd quoted in Martin Parry, Australia at cross roads as China boom ends, Fox News, 11 July 2013 , http://www foxnews.com/world/2013/07/11/australia-at-crossroads-as-china-boom-ends-pm/

72 Wayne Swan in Australian (sic) 'well placed' for transition, Sky News, 17 July 2013,

http://www.skynews.com.au/topstories/article.aspx?id=888757

73 Jacques When China Rules the World, p539
} 
to construct " $28,000 \mathrm{~km}$ of commuter rail and erect 20,000-50,000 skyscrapers." 74 Yet as a nation we must find ways to diversify our economy. ${ }^{75}$ To do so, we need to attract Chinese investment in noncommodity sectors, as well develop industries and services to meet the wants of China's growing middle class. The Asian Century will offer golden opportunities for the Australian economy. Australia's tourism industry, for example, should refocus its energies and target the Chinese to visit Australia. Australia's education sector, despite the dip in revenue in 2009-2010 due to publicised violence against Indians has enormous potential to attract students from wealthy Chinese families, and train Australians in in-demand skills. The manufacturing sector in Australia cannot compete with labour intensive, low priced goods from China and need to find niche markets, as Chinese technology is still playing catch up in several areas. The manufacturing sectors of China's south east Asian neighbours have responded to this challenge by becoming "...manufacturers of component parts assembled in China"76 Turning Northern Australia into 'Asia's food bowl' has been mooted by the Coalition, and while unfeasible with current technology, ${ }^{77}$ it displays that the parties are thinking of ideas to diversify.

Australian states should increase their own relations with China. Though section 51 of the Constitution grants the Federal Government exclusivity in foreign relations, nothing is stopping the states from setting up permanent trade missions in key Chinese cities, and sending regular delegations to visit stakeholders. These relations would be purely economical, in line with the Coalition governance method of compartmentalising relations. Whatever the eventual economic method of governance plan is, it should be used as a blueprint in the near future regarding Australia's economic relations with India and Indonesia, which are both on track to enter the top half dozen economies by 2050, thanks to their massive populations.

China has the right to pursue its own national interest, and as it is vastly more powerful, the rise of China does present some challenges to Australian foreign policy. They are not unique, however, and with opportunities that will emerge in the Asian Century, Australia is well positioned to continue its economic prosperity. Though a leader's time is a finite resource, each party in Australian politics has developed their own methods of governance to best utilise this resource in advancing the national interest and that diversity brings strength of imagination. The multilateral method of governance allows Australia to magnify its middle power status while the bilateral method of governance allows Australia to develop closer relations with other nations. Compartmentalising different aspects of the national interest such as trade and security has been able to serve many competing stakeholders. China needs Australia almost as much as Australia needs China, and it would be foolish for them to deliver some sort of ultimatum to the Australians to separate from the Americans - that would severely impact on the economy of both nations, and shatter the illusion of China's 'peaceful rise'. If the United States and China do for some unforseen reason go to war in the future, Australia, and every other country in the region, will have a lot more to worry about than flat screen TVs.

\footnotetext{
${ }^{74}$ Ibid p541

${ }^{75}$ Chris Bowen quoted in Bowen says China boom end a challenge, Sky News, 18 July 2013, http://www.skynews.com.au/topstories/article.aspx?id=888971

${ }^{76}$ Michael Wesley, 2012, Australia and the China boom in Australia and China at 40, University of New South Wales, Sydney, p200

${ }^{77}$ See Rob Law, The only way is up? The northern Australian food bowl fantasy, The Conversation, 18 March 2013, http://theconversation.com/the-only-way-is-up-the-northern-australian-food-bowl-fantasy-12573 and Bill Bellotti, Can Australia really feed Asia? The Conversation, 21 April 2013, http://theconversation.com/can-australia-really-feed-asia13626
} 


\section{Reference}

Tony Abbott, 2012, Address to the Heritage Foundation, Washington D.C., http://www.tonyabbott.com.au/LatestNews/Speeches/tabid/88/ArticleType/ArticleView/Article ID/8816/Default.aspx, accessed 4 July 2013

Tony Abbott, 2012, Address to AustCham Beijing, China, http://www.tonyabbott.com.au/News/tabid/94/articleType/ArticleView/articleId/8818/Addressto-AustCham-Beijing-China.aspx, accessed 4 July 2013

Australia as regional police doctrine puts Howard in damage control, ABC, 27 September 1999, http://www.abc.net.au/7.30/stories/s55116.htm accessed 26 February 2015

Hannah Beech, How China Sees the World, Time Magazine, 17 June 2013, New York, p23

Bill Bellotti, Can Australia really feed Asia? The Conversation, 21 April 2013, http://theconversation.com/can-australia-really-feed-asia-13626, accessed 18 July 2013

Nick Bisley, 2012 Never having to chose: China's rise and Australian Security in Australia and China at 40, University of New South Wales, Sydney, p67-68

Chris Bowen, Bowen says China boom end a challenge, Sky News, 18 July 2013, http://www.skynews.com.au/topstories/article.aspx?id=888971, accessed 19 July 2013

Colin Bradford \& Johannes Linn, 'The April 2009 London G-20 Summit in Retrospect', The Brookings Institution, 5 April 2010, www.brookings.edu/research/opinions/2010/04/05-g20summit-linn accessed 25th February 2015

Edmund Burke, 1886, Thoughts on the cause of the present discontents, http://www.unilibrary.com/ebooks/Burke,\%20Edmund\%20\%20Thoughts\%20on\%20Present\%20Discontents.pdf

Bush lauds Howard as 'man of steel', Sydney Morning Herald, 4 May 2003, http://www.smh.com.au/articles/2003/05/04/1051987592763.html accessed 22 February 2015

Jim Cairns, in interview with Robin Hughes, May 25, 1998, http://www.australianbiography.gov.au/subjects/cairns/interview7.html, accessed 14 Jan 2013

Rowan Callick, Party Time: Who Runs China and How, Black Inc, Collingwood,

Ben Chifley, speech to the NSW Labor Party Annual Conference, 12 June 1949, http://www.chifley.org.au/the-light-on-the-hill/ accessed 02 March 2015

James Curran, 2012, "The world changes: Australia's China policy in the wake of empire" in Australia and China at 40, University of New South Wales, Sydney

John Curtin, The Task Ahead, The Herald, 27 December 1941

John Curtin, the postscript to the news bulletin, Times, 7 May 1944

Alexander Downer, Neither Isolated nor Isolationist: The Legacy of Australia's Close Engagement with Asia, 9 August 2000, speech to the Murdoch University Asia Research Centre, http://www.foreignminister.gov.au/speeches/2000/000809_isolate.html accessed 5 March 2015

Gareth Evans, Outline of the Cambodian Peace Plan, Extract from Australian Senate Hansard, 24 November 1989, http://www.gevans.org/speeches/old/1989/241189_fm_outlinecambodia.pdf accessed 28 February 2015

Gareth Evans, Australia, Indo-China and the Cambodian Peace Initiative, Address to the Sydney Institute, Sydney, 13 March 1990,

http://www.gevans.org/speeches/old/1990/130390_fm_ausindochinecambodia.pdf accessed 28 February 2015

Gareth Evans, The Responsibility to Protect at 10: Progress, Challenges and Opportunities in the Asia Pacific, Address to APR2P/ GCR2P/ Stanley Foundation/ ICR toP Conference, Phnom Penh, Cambodia, 26 February 2015, http://www.gevans.org/speeches/speech568.html accessed 28 February 2015

George Friedman, Australia's Strategy, Stratfor, 22 May, 2012, http://www.stratfor.com/weekly/australias-strategy, accessed 25 July 2013

ESK Fung and C Mackerras, 1985, From Fear to Friendship; Australia's Policies towards the Peoples Republic of China, 1966-1982, University of Queensland Press, Brisbane 
Ross Garnaut, 1990, Australia and the Northeast Asian Ascendancy: Report to the Prime Minister and the Minister for Foreign Affairs and Trade, Second Edition, Australian Government Publishing Service, Canberra

Julia Gillard, The 7:30 Report, ABC, 5 October 2010, http://www.abc.net.au/7.30/content/2010/s3030288.htm accessed 25 February 2015

John Gorton, Australia's Prime Ministers, National Archives of Australia, $\mathrm{http} / /$ primeministers.naa.gov.au/primeministers/gorton/in-office.aspx accessed 5 March 2015

James Grubel, Bush's 'sheriff' comment causes a stir, The Age, 17 October 2003, http://www.theage.com.au/articles/2003/10/16/1065917555365.html accessed 22 February 2015

Allan Gyngell \& Michael Wesley, 2003, Making Australian Foreign Policy, Cambridge University Press, Port Melbourne

Ian Hancock, 2002 John Gorton: He Did It His Way, Hodder, Sydney

Peter Hartcher, On the road to China, no Damascus conversion, 15 May 2012, Sydney Morning Herald, http://www.smh.com.au/federal-politics/political-opinion/on-the-road-to-china-nodamascus-conversion-20120514-1ymw4.html\#ixzz2Ye9GXp00, accessed 20 July 2013

Peter Hartcher, 2014, The Adolescent Country, The Lowy Institute, Penguin, Melbourne

Martin Jacques When China Rules the World, $2^{\text {nd }}$ Edition, Penguin, London

Paul Keating, Embargoed against delivery, Asia in the New Order: Australia's Diminishing Sphere of Influence, 14 November 2012, The Keith Murdoch Oration State Library of Victoria

Zachary Keck's The Hard Side of Soft Power, The Diplomat, 24 July 2013, http://thediplomat.com/the-editor/2013/07/24/the-hard-side-of-soft-power/, accessed 24 July 2013

Rob Law, The only way is up? The northern Australian food bowl fantasy, The Conversation, 18 March 2013, http://theconversation.com/the-only-way-is-up-the-northern-australian-food-bowlfantasy-12573, accessed 22 July 2013

Susan V. Lawrence and Michael F. Martin's Understanding China's Political System, Congressional Research Service Report for (US) Congress

Brian Loughnane (auth), 2002, The Federal Platform of the Liberal Party of Australia, Liberal Party of Australia, http://lpaweb-static.s3.amazonaws.com/FederalPlatform.pdf accessed 5 March 2015

Derek McDougall, 1997, Studies in International Relations: The Asia-Pacific, The Nuclear Age, Australia, Second Edition, Hodder Education, Rydalmere

William McMahon, New Prime Minister's Press Conference, 10 March 1971, http://pmtranscripts.dpmc.gov.au/transcripts/00002381.pdf accessed 4 March 2015

William McMahon Australia's Prime Ministers, National Archives of Australia, http://primeministers.naa.gov.au/primeministers/momahon/in-office.aspx accessed 4 March 2015

FA Mediansky \& AC Palfreeman, eds., In Pursuit of National Interests: Australian Foreign Policy in the 1990s, Pergamon Press, Sydney, 1988

Robert Menzies, Wartime Broadcast, 3 September 1939, https://www.awm.gov.au/encyclopedia/prime_ministers/menzies/accessed 4 March 2015

T.B Millar, From Whitlam to Fraser, Foreign Affairs, July 1977, http://www.foreignaffairs.com/articles/27902/tb-millar/from-whitlam-to-fraser accessed 6 March 2015

Hans Morgenthau, 1967, Politics Among Nations: The Struggle for Power and Peace, Alfred A. Knopf, New York

Annabelle Quince \& Kerry Phillips, Trading with the enemy: the Australia-Japan Agreement on Commerce, ABC, 25 February 2007, http://www.abc.net.au/radionational/programs/rearvision/trading-with-the-enemy-the-australiajapan/3393730 accessed 6 March 2015

Gideon Rose, 1998, "Neoclassical Realism and Theories of Foreign Policy", World Politics, Vol. 51, No 1, Oct., pp144-172, http://www.jstor.org/stable/25054068> accessed 17 March 2014 
Kevin Rudd in Phillip Coorey's How zhengyou Kevin is keeping everyone happy, 11 April 2008, Sydney Morning Herald, http://www.smh.com.au/news/world/how-zhengyou-kevin-is-keepingeveryone-happy/2008/04/10/1207420587841.html, accessed 10 July 2013

Kevin Rudd in Dennis Shanahan, Kevin Rudd spruiks merits of G20 to the UN, The Australian, 25 September 2009, http://www.theaustralian.com.au/news/world/kevin-rudd-spruiks-merits-ofg20-to-the-un/story-e6frg6so-1225779334335 accessed 20 February 2015

Kevin Rudd in Martin Parry's Australia at cross roads as China boom ends, Fox News, 11 July 2013, http://www.foxnews.com/world/2013/07/11/australia-at-crossroads-as-china-boom-ends-pm/, accessed 10 July 2013

Glenn Stevens, The Challenge of Prosperity, Address to the Committee for Economic Development of Australia (CEDA) Annual Dinner, 29 November 2010, http://www.rba.gov.au/speeches/2010/sp-gov-291110.html, accessed 12 July 2013

Wayne Swan in Australian (sic) 'well placed' for transition, Sky News, 17 July 2013, http://www.skynews.com.au/topstories/article.aspx?id=888757, accessed 19 July 2013

Bush lauds Howard as 'man of steel', Sydney Morning Herald, 4 May 2003, http://www.smh.com.au/articles/2003/05/04/1051987592763.html accessed 22 February 2015

Peg White \& Peter Young, 1988, Australia's Relations with Asia, McGraw-Hill Book Company, Sydney

Gough Whitlam, Australia and International Law - Address by the Prime Minister to the Seminar on Public International Law, Canberra, 26 July 1975, Whitlam Institute E-Collection at 2: http://cem.uws.edu.au/R/F6TBHIGNYUKUV33HDQBGXS19MQKA6S2D429T1M6H6QA9 KDNV6Y-00203?func $=$ results-jumpfull\&set_entry=000001\&set_number $=000003 \&$ base $=$ GEN01-EGW01 accessed 5 March 2015

Gough Whitlam, 1997, Abiding Interests, University of Queensland Press, St Lucia, QLD

George Wright (auth), 2011, Australian Labor Party National Platform, Australian Labor Party, http://d3n8a8pro7vhmx.cloudfront.net/australianlaborparty/pages/121/attachments/original/136 5135867/Labor_National_Platform.pdf?1365135867 accessed 4 March 2015 